CLINICAL STUDY

\title{
Contrasting cellular and humoral autoimmunity associated with latent autoimmune diabetes in adults
}

\author{
A Mayer ${ }^{1,2,4}$, N Fabien ${ }^{2}$, M C Gutowski ${ }^{2}$, V Dubois $^{3}$, L Gebuhrer ${ }^{3}$, J Bienvenu ${ }^{2}$, J Orgiazzi ${ }^{2,4}$ and A M Madec $^{4}$ \\ ${ }^{1}$ Department of Endocrinology, Centre Hospitalier de Chambery, 73000, Chambery, France, ${ }^{2}$ Centre Hospitalier Lyon Sud, 69310 Pierre-Benite, France, \\ ${ }^{3}$ Etablissement Français du Sang Rhône-Alpes, 69007 Lyon, France and ${ }^{4}$ INSERM U449-UCBL, 69008 Lyon, France
}

(Correspondence should be addressed to A Mayer; Email: anne.mayer@ch-chambery.fr)

\begin{abstract}
Objective: Diabetes is clinically classified into two types: type 1 (T1D) and type 2 diabetes (T2D). Nevertheless, intermediate forms of diabetes are frequent and difficult to recognize and manage appropriately. In this study, we investigated whether patients with intermediate form of diabetes, here called unclassified diabetes (UD), have $\beta$-cell autoimmune markers.

Research design and methods: $\beta$-cell autoimmune markers ( $\beta$-cell autoantibodies $(\mathrm{aAb})$, peripheral blood mononuclear cells (PBMC) responsive to five islet proteins, cytokine secretion, and human leukocyte antigen (HLA)-DQB1 genotypes) were analyzed in 50 UD patients, 23 age- and HLA-matched normal control subjects, and 23 classic T2D patients.

Results: We observed that 16 out of 50 (32\%) UD patients demonstrated responsive PBMCs, as opposed to 1 out of $23(5 \%)$ age- and HLA-matched normal control subjects, and 0 out of 23 classic T2D patients. Overall, 29 (58\%) UD patients had at least one marker of $\beta$-cell autoimmunity ( $\beta$-cell aAb and/or PBMC autoreactivity), in association with high-risk HLA genotypes DQB1*0201 and/or DQB1*0302. Moreover, the 13 (26\%) UD patients who had $\beta$-cell aAb were not the same as those with PBMC autoreactivity, except for one patient. Patients with PBMC autoreactivity were older at the onset of the disease and had a better residual $\beta$-cell function than those with $\beta$-cell aAb.

Conclusions: Our data confirm that T-cell autoimmunity can be detected in latent autoimmune diabetes in adults patients. We show an inverse correlation between humoral and cellular $\beta$-cell autoimmunities. Possible protective cellular responses in the patients with $\beta$-cell PBMC autoreactivity could have potential therapeutic implications.
\end{abstract}

European Journal of Endocrinology 157 53-61

\section{Introduction}

The World Health Organization defines two major types of diabetes mellitus: type 1 (T1D) and type 2 diabetes (T2D). T1D results from T-cell-mediated autoimmune destruction of $\beta$-cells of the pancreas, whereas T2D is characterized by insulin resistance with a non-autoimmune insulin secretory defect (1). However, discriminating between T1D and T2D can be very difficult in clinical practice. Thus, an intermediate form of autoimmune diabetes has been described, by different investigators, for more than 20 years (2-5). At present, this intermediate form of autoimmune diabetes is often called latent autoimmune diabetes in adults (LADA), but remains poorly understood at both clinical and research levels (6-8). The diagnosis of LADA is currently based on three criteria: (1) adult age at the onset of diabetes; (2) presence of circulating $\beta$-cell autoantibodies (aAb), which distinguishes LADA from T2D; and (3) lack of requirement for insulin for at least 6 months after diagnosis, which distinguishes LADA from classic T1D (6). In the UK Prospective Diabetes Study, about $10 \%$ of adults with presumed T2D had circulating $\beta$-cell aAb, and the majority progressed to insulin dependence within 6 years (9). Therefore, LADA is an important form of diabetes, although it is frequently underestimated. However, because LADA is more common than classic childhood T1D and more progressive in evolution, immunomodulatory therapies such as anti-CD3 could be more effective in this subgroup of autoimmune diabetes (10).

Presence of peripheral blood mononuclear cells (PBMC) reacting to several $\beta$-cell autoantigens has been demonstrated in patients with a new onset T1D (11-15). Likewise, we have previously shown PBMC autoreactivity to insulin in $32 \%$ of recent-onset T1D and to GAD peptides in $67 \%$ of them $(16,17)$. Little is known about T-cell reactivity in LADA, probably because of difficulties in accurately recognizing the disease in the studied population. Only one study reported PBMC from islet antibody-positive patients with phenotypic T2D as reacting to lysed human pancreatic islets (18). Studies of pancreatic histology in LADA are limited to a single report on a 65-year-old Japanese woman, which revealed T-cell infiltration of islets (insulitis) and significant residual $\beta$-cell mass (19). 
Because LADA remains relatively difficult to define accurately, we have elected to study 50 diabetic patients with intermediate forms of diabetes, here called unclassified diabetes (UD). UD patients were characterized by the lack of the immediate need for insulin therapy usually observed in classic T1D, as well as by the lack of the metabolic syndrome usually observed in classic T2D. We have investigated how these UD patients differ from T1D, T2D, and healthy controls in terms of anti- $\beta$-cell antibodies and T-cell autoreactivity, as well as in their peripheral cytokine production.

\section{Subjects and methods}

\section{Patients}

Fifty patients with UD, 26 women and 24 men, aged $54.4 \pm 10.3$ years $($ mean \pm s.D. $)$ were recruited consecutively in our diabetes center in Lyon-Sud Hospital between 2000 and 2003. The intermediate form of diabetes was determined by diabetologists, based on the lack of requirement for insulin for at least 6 months after diagnosis and the lack of dysmetabolic syndrome. Moreover, the entry criteria were: at least two fasting plasma glucose results $>7 \mathrm{mmol} / \mathrm{l}$ for more than 6 months, diabetes duration of $<15$ years, no previous insulin therapy, age $>30$ and $<75$ years, absence of concomitant general disease, and no pregnancy. At the time of the study, diabetes duration was $4.5 \pm 4.3$ (range $0.5-14)$ years. All patients were clinically evaluated initially and 3-6 years later. The mean follow-up was $5.9 \pm 4.9$ years for 48 out of 50 patients. Presence of familial history of diabetes (T1D and/or T2D) was recorded, as well as familial or personal history of autoimmune disease (autoimmune thyroid diseases, pernicious anemia, autoimmune hepatitis, and vitiligo). Dysmetabolic syndrome, treated or not, was evaluated according to the following criteria: hyperglycemia and at least two features among central obesity, high blood pressure $\geq 130 / 85$, hypertriglyceridemia $>1.69 \mathrm{mmol} / \mathrm{l}$ and HDL cholesterol <1.04 (male) or 1.29 (female) $\mathrm{mmol} / \mathrm{l}(20)$. Blood samples for the following determinations were collected on the same day: blood glycated hemoglobin levels (HPLC assay; normal range 4.5-6.1\%), C-peptide stimulation $6 \mathrm{~min}$ after glucagon injection (RIA; normal range 0.30-1.2 nmol/l), HLA-DQB1 genotypes, $\beta$-cell aAbs, T-cell reactivity, and cytokines (see below).

The clinical and immunological characteristics of these 50 UD patients were compared with those of 23 matched (for age, sex, and HLA) control subjects: 13 women and 10 men, aged $52.5 \pm 7.3$ years; with those of 23 classical T2D patients: 7 women and 16 men, aged $53.5 \pm 7.0$ years; and with those of 44 classical

Table 1 Clinical data of unclassified diabetic (UD) patients as compared with matched (for age, sex, and HLA) healthy control subjects and type 2 diabetic (T2D) patients.

\begin{tabular}{|c|c|c|c|c|c|}
\hline & UD patients & $\begin{array}{l}\text { Healthy control } \\
\text { subjects }\end{array}$ & $\begin{array}{c}P \text { UD versus } \\
\text { control } \\
\text { subjects }\end{array}$ & T2D patients & $\begin{array}{c}P \text { UD versus } \\
\text { T2D }\end{array}$ \\
\hline$n$ & 50 & 23 & & 23 & \\
\hline Age (years) & $54.4+10.3$ & $51.3+9.2$ & NS & $53.5+8.5$ & NS \\
\hline Sex & $26 \mathrm{~F} / 23 \mathrm{M}$ & $13 \mathrm{~F} / 10 \mathrm{M}$ & NS & $7 \mathrm{~F} / 16 \mathrm{M}$ & NS \\
\hline $\mathrm{BMI}\left(\mathrm{kg} / \mathrm{m}^{2}\right)$ & $24.0 \pm 2.2$ & $23.3 \pm 2.8$ & NS & $32.5 \pm 3.5$ & $4.10^{-12}$ \\
\hline Age at diabetes onset (years) & $50.4 \pm 9.8$ & & & $48.1 \pm 9.7$ & NS \\
\hline Duration of diabetes (years) & $4.5 \pm 4.3$ & & & $6.1 \pm 4.7$ & NS \\
\hline $\mathrm{HbA1c}(\%)$ & $9.6+2.2$ & & & $8.6+1.6$ & 0.01 \\
\hline Basal C-peptide (nmol/l) & $0.6 \pm 0.5$ & & & $0.6 \pm 0.4$ & NS \\
\hline Insulin therapy after study & $27(54)$ & & & 0 & $5.10^{-6}$ \\
\hline Familial history of diabetes & $30(60)$ & $1(4)$ & & $15(65)$ & NS \\
\hline Familial or personal history of autoimmunity & $22(44)$ & 0 & & 0 & 0.001 \\
\hline Dysmetabolic syndrome & $10(20)$ & 0 & & $13(59)$ & 0.002 \\
\hline \multicolumn{6}{|l|}{ HLA genotypes } \\
\hline $\mathrm{DQB} 1{ }^{*} 0201$ and/or *0302 & $34(68)$ & $9(41)$ & NS & & \\
\hline DQB $1{ }^{*} 0201$ and ${ }^{*} 0302$ & $5(10)$ & $1(5)$ & NS & & \\
\hline $\mathrm{DQB} 1^{\star} 0201 / x^{\mathrm{a}}$ & $27(54)$ & $5(23)$ & NS & & \\
\hline $\mathrm{DQB} 1^{*} 0302 / y^{\mathrm{b}}$ & $12(24)$ & $3(14)$ & NS & & \\
\hline DQB1*0602 & $21(42)$ & $14(64)$ & NS & & \\
\hline$\beta$-cell autoantibodies & $14(28)$ & 0 & 0.007 & 0 & 0.007 \\
\hline PBMC autoreactivity against $\beta$-cell & $16(32)$ & $1(4)$ & 0.009 & 0 & 0.007 \\
\hline \multicolumn{6}{|l|}{ Cytokines } \\
\hline IFN- $\gamma(\mathrm{U} / \mathrm{ml})$ & $519.8 \pm 396.7$ & $184.1 \pm 203.1$ & 0.02 & & \\
\hline $\mathrm{IL}-12(\mathrm{pg} / \mathrm{ml})$ & $258.5 \pm 208.4$ & $226.3 \pm 217.6$ & NS & & \\
\hline IL-4 (pg/ml) & $228.6 \pm 174.5$ & $105.2 \pm 94.8$ & 0.006 & & \\
\hline $\mathrm{IL}-10(\mathrm{pg} / \mathrm{ml})$ & $1192.0 \pm 857.1$ & $563.6 \pm 552.1$ & 0.0002 & & \\
\hline
\end{tabular}

Data are $n(\%)$, except when precised. aAb, autoantibodies; PBMC, peripheral blood mononuclear cells.

${ }^{a} x$ other than ${ }^{*} 0201$.

by other than ${ }^{*} 0302$. 
recent-onset T1D patients: 24 females and 20 males, aged $14 \pm 7.1$ years, included in 1997 (data previously published (16); Table 1). The study protocol was approved by our local ethical committee. Informed consent was obtained from all participants.

\section{Autoantibody assays}

A systematic screening of four islet aAbs was performed in all the patients.

Islet cell aAbs (ICA) ICA were determined using an indirect immunofluorescence assay. The end-point dilution causing detectable fluorescence was converted into Juvenile Diabetes Foundation Units using a standard curve obtained with an international reference serum. The detection limit was 3 Juvenile Diabetes Foundation Units.

Anti-GAD and anti-IA2 antibodies (GADA and IA2A) were determined using in vitro translated $\left.{ }^{35} \mathrm{~S}\right] \mathrm{GAD} 65$ and $\left[{ }^{35}\right.$ S]IA2 as previously described (21). Plasmid cDNA encoding for full-length GAD65 cloned into the pcDNAII-vector (Dr A Lernmark, Seattle, USA) and cDNA encoding for the cytoplasmic part of IA2 (aa603979) cloned into the pSP64poly(A) vector (Dr MC Christie, London, UK) were amplified in the Escherichia coli XL1 blue. GADA and IA2A were measured in duplicate using in vitro transcribed and translated recombinant human protein and precipitation with protein A-Sepharose as previously reported (22). After washing, bound counts were expressed as arbitrary units using a pool of positive sera with an arbitrary value of 1.27 for GAD and 100 for IA2. GADA activity above $0.11 \mathrm{U}$ and IA2A activity above $1 \mathrm{U}$ were considered as positive, corresponding to the mean +3 S.D. value of 95 controls. The performance of the assays is monitored by a set of quality controls and participation in external laboratory proficiency comparison. The laboratory has participated in the Diabetes Antibody Standardization Program and scored 78\% for sensitivity and $95 \%$ for specificity in the GADA assay, and $70 \%$ sensitivity and $98 \%$ specificity for IA2A (23).

Insulin aAbs (IAA) IAA were assayed by RIA using ${ }^{125}$ I-labeled human insulin (Sanofi Diagnostic Pasteur, Marnes la Coquette, France). IAA activity of $0.50 \%$ was considered positive.

\section{T-cell reactivity}

PBMC stimulation was investigated as previously described $(16,17)$. Peripheral venous blood was drawn between 0800 and $0900 \mathrm{~h}$ into sterile heparinized tubes and was processed within $2 \mathrm{~h}$. Mononuclear cells were isolated under sterile conditions by centrifugation in Ficoll Histopaque 1077 (Sigma). Cell viability was always above 90\% using Trypan blue stain (Biowhittaker, Verviers,
Belgium) exclusion. After washing, cells were resuspended in RPMI 1640 medium (Biowhittaker) supplemented with $50 \mathrm{UI} / \mathrm{ml}$ penicillin-streptomycin (Sigma), $2 \mathrm{mM}$-glutamine (Sigma), and $10 \%$ pooled human AB + serum (Sigma). PBMC $\left(1.5 \times 10^{5}\right)$ were distributed in $180 \mu \mathrm{l}$ aliquots in round-bottomed 96-well plates and $20 \mu \mathrm{l}$ antigen solution or medium alone was added to quadruplicate wells. PBMC were incubated in the presence of either no antigen, control antigens - human serum albumin (HSA) at $10 \mu \mathrm{g} / \mathrm{ml}$, purified tetanus toxin (TT) at $10 \mu \mathrm{g} / \mathrm{ml}$ (Pasteur, Paris, France), and polyclonal activator interleukin-2 (IL-2) at $75 \mathrm{U} / \mathrm{ml}$ (Hoffman La Roche) - or $\beta$-cell autoantigens - recombinant human insulin expressed in yeast (Sigma) at three final concentrations, 1,10 , and $20 \mu \mathrm{g} / \mathrm{ml}$, recombinant human B9-23 peptide of insulin (Sigma) at three dosages, 1,10 , and $20 \mu \mathrm{g} / \mathrm{ml}$, recombinant human GAD65 at $5 \mu \mathrm{g} / \mathrm{ml}$ (gift from P van Endert, INSERM U580, Paris, France), synthetic GAD peptides (three peptide pools consisting of 10 or 11 overlapping peptides (65-77 amino acids)) spanning the C-terminal GAD 65 molecule (GAD65 region (379-585)) at $5 \mu \mathrm{g} / \mathrm{ml}$ (gift from $\mathrm{C}$ Granier, CNRS-UMR5160, Montpellier, France; (23)), and recombinant human IA2 at $10 \mu \mathrm{g} / \mathrm{ml}$ (gift from P van Endert, INSERM U580). The most frequent proliferative responses were obtained with $10 \mu \mathrm{g} / \mathrm{ml}$ for the whole antigen molecules and $20 \mu \mathrm{g} / \mathrm{ml}$ for peptides. The data presented correspond to those obtained with these concentrations of antigens. All the antigens and media used were tested and certified endotoxin free by the Pharmacy Laboratory, Ed. Herriot Hospital, Lyon, France. PBMC were cultured in a total volume of $200 \mu$ for 7 days at $37^{\circ} \mathrm{C}$ in $5 \% \mathrm{CO}_{2}$. After 6 days, $10 \mu \mathrm{l} \mathrm{RPMI}$ containing $1 \mu \mathrm{Ci}\left[{ }^{3} \mathrm{H}\right]$ thymidine (NEN, Boston, MA, USA) was added to each well and the incubation was continued for 16-18 h. Cultures were then harvested and $\left[{ }^{3} \mathrm{H}\right]$ thymidine incorporation into the cells was semiautomatically measured by liquid scintillation counting. The mean value of each quadruplicate was calculated. The intra- and inter-assay coefficients of variation ranged from 4 to $47 \%$ (mean $\approx 30 \%$ ). Proliferation was expressed as a stimulation index (SI), which corresponded to the ratio of the c.p.m. of PBMC in the presence of antigen divided by c.p.m. of PBMC without antigen. An SI $>3.0$ was considered as positive, i.e. above the mean +3 s.D. of controls.

\section{Cytokines}

Cytokine production was evaluated by two different methods. a) Whole-blood IL-12, IFN- $\gamma$, IL-4, and IL-10 production assay (ELISA assay). Peripheral venous blood from all diabetic patients and all healthy control subjects was drawn into sterile heparinized tubes as described. Whole blood (100 $\mu \mathrm{l}$ aliquots) was diluted to a total volume of $1 \mathrm{ml}$ with RPMI 1640 medium containing $10 \%$ fetal calf serum (Boehringer Ingelheim Bioproducts, Gagny, France) in 24-well tissue culture 
plates. Blood cultures were incubated at $37^{\circ} \mathrm{C}$ in $5 \% \mathrm{CO}_{2}$ with either no antigen or phytohemagglutinin (PHA) at $10 \mu \mathrm{g} / \mathrm{ml}$ (Sigma). After $48 \mathrm{~h}$, supernatants were harvested and stored at $-80^{\circ} \mathrm{C}$ until assay for IL-12, IFN- $\gamma$, IL-4, and IL-10 contents by ELISA (Medgenix EASIA kit, Biosource, Rungis, France). b) IL-4 and IFN- $\gamma$ secretion assay (whole-blood MACS cytokine secretion assay (Miltenyi Biotec, Paris, France)). Peripheral venous blood from 16 out of 60 diabetic patients and from 17 out of 22 healthy control subjects was drawn into sterile heparinized tubes as described. Blood $(5 \mathrm{ml})$ was incubated for $16 \mathrm{~h}$ at $37^{\circ} \mathrm{C}$ in the presence of either no activator or $3 \mu \mathrm{g} / \mathrm{ml}$ staphylococcus enterotoxin B (SEB, Sigma). After erythrocyte lysis and washing, cell pellets were resuspended and labeled with cytokine-specific (IL4 or IFN- $\gamma$ ) catch reagent and were incubated for $45 \mathrm{~min}$ at $37{ }^{\circ} \mathrm{C}$ in RPMI supplemented with $10 \% \mathrm{AB}$ human serum. During the incubation period, secreted cytokines were immediately caught on the cell surface. After washing, cells were labeled for 10 min on ice, by respective cytokine detection reagent (antibody conjugated with phycoerythrin (PE)) and counter labeled by CD8 + FITC/or CD4+FITC and CD3 + PC5 (Immunotech, Marseille, France). Cells were further washed and labeled for $15 \mathrm{~min}$ at $8^{\circ} \mathrm{C}$ with anti-PE microbeads. After washing and resuspension in $1 \mathrm{ml}$ of PBS, $0.5 \%$ BSA, 2 mM EDTA buffer, magnetic separation of cytokinespecific $\mathrm{CD} 3+, \mathrm{CD} 8+$, or $\mathrm{CD} 4+$ secreting cells was performed using two subsequent MS columns (Miltenyi Biotec) with cytokine-specific antibody conjugated to PE. Finally, cells were analyzed by flow cytometry (Beckman Coulter XL2, Miami, FL, USA). The whole-blood MACS cytokine secretion assay was performed in the 16 first UD patients who appeared to have the following characteristics: ten had no anti- $\beta$-cell antibodies and no T-cell autoreactivity, four had only T-cell autoreactivity, and two had only anti- $\beta$-cell antibodies.

\section{HLA-DQB1 genotypes}

Genetic studies were performed in the Blood Transfusion Center of Lyon, France. All diabetic patients and control subjects were typed for HLA-DQ by PCR amplification using sequence-specific primers (PCR-SSP; Dynal SSPsets, Compiegne, France). All phenotypically different HLA-DQA1* and DQB1* alleles recognized by the HLA Nomenclature Committee in 1994 were individually identified. In our reference population, $2 \%$ were HLADQB ${ }^{*} 0201 / 0302,45 \%$ HLA-DQB1 $* 201 / x$ or HLADQB1*0302/y, and 20\% HLA-DQB1*0602/z (24).

\section{Statistical analysis}

The values are presented as mean and s.D. All data for this cross-sectional study were analyzed using the statistical package SPSS for Windows. The MannWhitney test was used for quantitative data. The Fisher's exact test was used to test qualitative data.
A $P$ value of 0.05 or less was considered statistically significant. Multiple comparisons were corrected by the Bonferroni adjustment.

\section{Results}

The clinical characteristics of UD and T2D patients are shown in Table 1. Clinical characteristics of T1D patients were previously described (16). Body mass index was higher in T2D than in UD patients $(32.5 \pm 3.5$ vs $24.0 \pm$ $\left.2.2 ; P=4.10^{-12}\right)$. There were no differences in the frequency or in the type of diabetes in the familial histories of T2D and UD patients. On the other hand, patients with UD had more frequently a personal or familial history of autoimmune disease (59 vs $0 \% ; P=0.001$ ). Age at diabetes onset and duration were similar. HbAlc was higher in UD patients $(9.6 \pm 2.2$ vs $8.6 \pm 1.6 ; P=0.01)$. Basal and stimulated C-peptide values were not different between the two subgroups.

\section{$\beta$-cell autoantibodies}

Of the 50 UD patients, 14 (28\%) had at least one positive $\beta$-cell aAb compared with no control subjects and no T2D patients $(P=0.007$; Table 1$)$. Among these 14 UD patients, $8(62 \%)$ had GADA, $8(62 \%)$ had IAA, 7 (54\%) had ICA, and $2(12 \%)$ had IA2A. Eight (57\%) had only one positive $\beta$-cell $\mathrm{aAb}$, three $(21 \%)$ had two positive $\beta$-cell aAbs, two (14\%) had three positive $\beta$-cell aAbs, and one $(7 \%)$ had four positive $\beta$-cell aAbs. For comparison, 36 out of 44 CT1D patients $(82 \%)$ had at least one positive $\beta$-cell aAb.

\section{T-cell reactivity}

PBMC of 16 out of $50(32 \%)$ UD patients elicited significant proliferation in the presence of at least one $\beta$-cell autoantigen (Fig. 1). For comparison, 0 out of 23 T2D patients $(P=0.007)$ and 1 out of $23(4 \%)$ HLAmatched control subjects $(P=0.009)$ had at least one PBMC reactivity. This HLA-matched control subject showed PBMC reactivity to GAD peptide. Note that she had a familial history of diabetes. Human insulin and human GAD65 were the more prevalent stimulatory antigens, with 7 out of $16(44 \%)$ patients reacting to these antigens in each case (mean SI of $2.5 \pm 3.3$ for insulin and $1.9 \pm 2.6$ for GAD65). PBMC from 4 out of $16(25 \%)$ UD patients reacted to insulin peptide B9-23 (mean SI $=1.8 \pm 1.3)$. PBMC from 4 out of $16(25 \%)$ patients reacted to $\mathrm{GAD}$ peptides (mean $\mathrm{SI}=1.7 \pm 1.2$ ), and 2 out of $16(12 \%)$ reacted to IA2 (mean SI $=1.5 \pm$ $0.7)$. PBMC from four patients $(25 \%)$ reacted to three antigens, PBMC from one patient $(6 \%)$ reacted to two antigens, and PBMC from 11 patients (69\%) reacted to one antigen. No PBMC reacted to all five or even four antigens. Out of 50 UD patients, 7 (14\%) had PBMC reactivity against insulin compared with 14 out of 44 


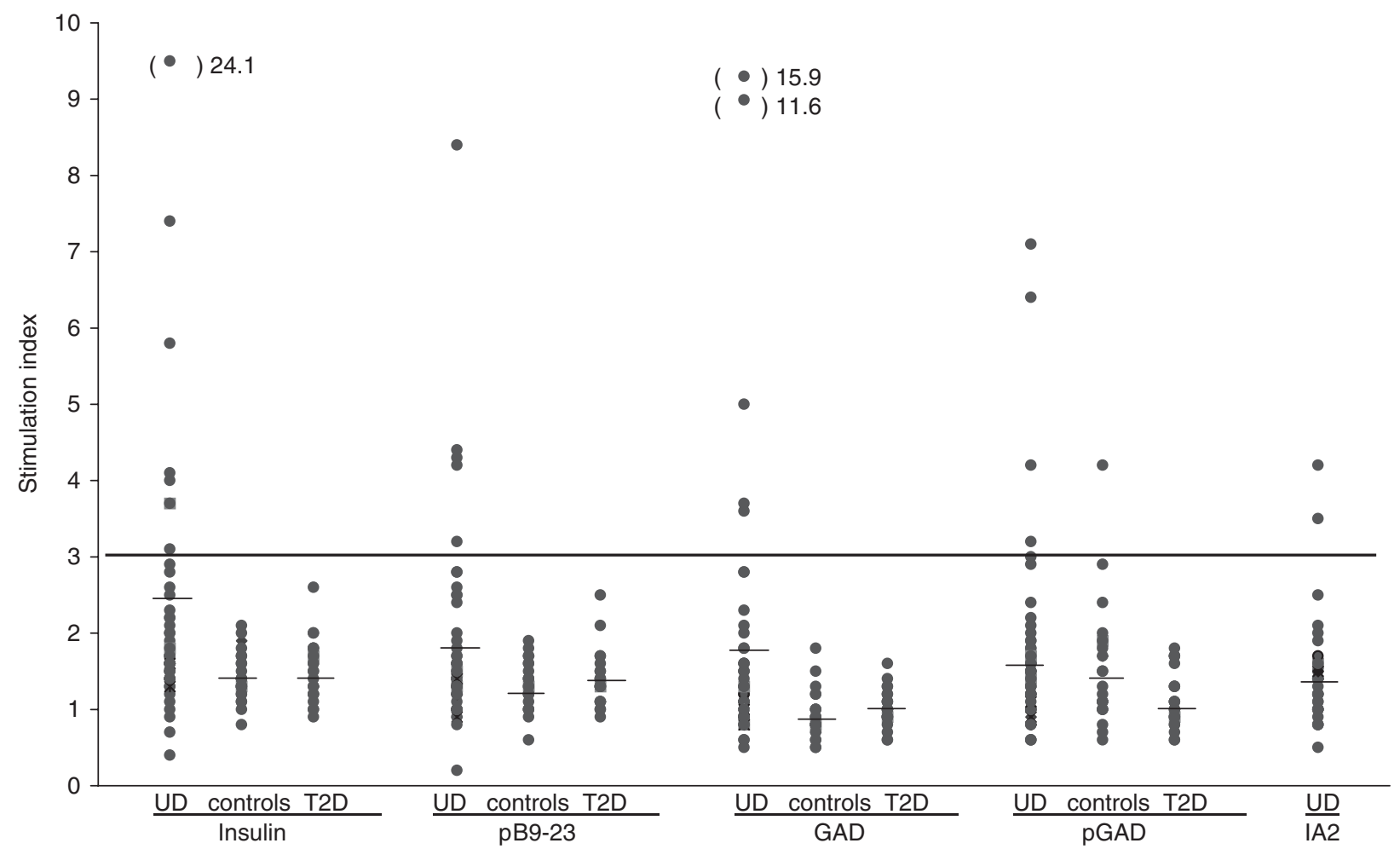

Figure 1 T-cell reactivity against insulin, insulin peptide B9-23 (pB9-23), glutamic acid decarboxylase (GAD), GAD peptides (pGAD), and insulinoma-associated protein 2 (IA2) in the different groups studied (unclassified diabetic (UD) patients, control subjects, and type 2 diabetic (T2D) patients). The horizontal line represents the limit of positivity (stimulation index $\geq 3$ ) for T-cell reactivity. PBMC of 16 out of 50 (32\%) UD patients elicited significant proliferation in the presence of at least one $\beta$-cell autoantigen (7 out of 16 (44\%) against insulin, 7 out of 16 (44\%) against GAD65, 4 out of $16(25 \%)$ against insulin peptide B9-23, 4 out of $16(25 \%)$ against GAD, and 2 out of $16(12 \%)$ reacted to IA2). For comparison, 0 out of 23 T2D patients $(P=0.007)$ and 1 out of $23(4 \%)$ HLA-matched control subjects $(P=0.009)$ had at least one PBMC reactivity.

(32\%) T1D. Similarly, 4 out of 50 (8\%) UD patients had PBMC reactivity against GAD peptides compared with 14 out of $21(67 \%)$ T1D.

\section{Distribution of autoimmune markers in patients with UD}

Among the 29 patients with $\beta$-cell autoimmunity, only one diabetic patient (3\%) was positive for both $\beta$-cell autoantibody and T-cell reactivity (Fig. 2). Fourteen $(28 \%)$ had at least one $\beta$-cell autoantibody without any T-cell reactivity and $16(32 \%)$ had at least one positive PBMC autoreactivity without any $\beta$-cell autoantibody, suggesting a lack of association or even an inverse relationship between cellular and humoral autoimmunities $\left(P=6 \cdot 10^{7}\right)$. Because of this inverse relationship between cellular and humoral autoimmunities, we have compared the characteristics of UD patients according to the presence of $\beta$-cell autoantibody or T-cell reactivity (Table 2). UD patients with T-cell reactivity were older at diabetes onset $(58.5 \pm 10.0$ vs $48.1 \pm 10.1$ years; $P=$ 0.004), had higher stimulated C-peptide levels $(0.8 \pm$ $0.5 \mathrm{nmol} / \mathrm{l}$ vs $0.4 \pm 0.3 ; P=0.01$ ), and required less frequent insulin therapy after a mean follow-up of 6 years (6 (49\%) vs $11(79 \%) ; P=0.04)$, as compared with UD patients with humoral autoimmune markers. No difference in cytokine production was seen between UD patients with $\beta$-cell aAbs and patients with T-cell reactivity.

\section{Cytokines}

IFN- $\gamma$, IL-4, and IL-10 production by PBMC after PHA stimulation (ELISA) were enhanced in all UD patients as compared with the control subjects (IFN- $\gamma$ : $519.8 \pm 396.7$ vs $184.1 \pm 203.1 \mathrm{U} / \mathrm{ml}, \quad P=0.02$; IL-4: $228.6 \pm 174.5$ vs $105.2 \pm 94.8 \mathrm{pg} / \mathrm{ml}, P=0.006$; IL-10: $\quad 1192.0 \pm 575.6$ vs $563.6 \pm 552.1 \mathrm{pg} / \mathrm{ml}$, $P=0.0002)$. No difference was found for IL-12 production. A MACS cytokine secretion assay using polyclonal stimulation by SEB confirmed these results. The percentage of secreting IFN- $\gamma$ T-cells, especially CD8 +, was higher in UD patients than in controls $(6.39 \pm 4.38$ vs $3.15 \pm 2.14 \%$ of lymphocytes; $P=0.02)$. Likewise, the percentage of secreting IL-4 CD4+T-cells was higher in UD patients than in controls $(2.25 \pm 1.49$ vs $0.58 \pm 0.57 \%$ of lymphocytes; $P=0.003$; Fig. 3). No detectable cytokine production on antigen-specific stimulation could be obtained. 
Table 2 Characteristics of unclassified diabetic (UD) patients according to presence of $\beta$-cell autoantibody or peripheral blood mononuclear cells (PBMC) reactivity.

\begin{tabular}{|c|c|c|c|}
\hline & Presence of $\beta$-cell autoantibody & Presence of PBMC reactivity & $\boldsymbol{P}$ \\
\hline$n$ & $14(28)$ & $16(32)$ & \\
\hline Age (years) & $48.1 \pm 10.1$ & $58.5 \pm 10.0$ & 0.004 \\
\hline Sex & $9 \mathrm{~F} / 5 \mathrm{M}$ & $6 \mathrm{~F} / 10 \mathrm{M}$ & NS \\
\hline $\mathrm{BMI}\left(\mathrm{kg} / \mathrm{m}^{2}\right)$ & $24.1 \pm 2.6$ & $24.6 \pm 2.2$ & NS \\
\hline Age at diabetes onset (years) & $43.9 \pm 9.0$ & $53.6 \pm 10.5$ & 0.006 \\
\hline Duration of diabetes (years) & $4.3 \pm 4.4$ & $5.1 \pm 4.2$ & NS \\
\hline $\mathrm{HbA1c}(\%)$ & $9.1 \pm 2.1$ & $9.0 \pm 1.6$ & NS \\
\hline Increment above basal C-peptide (nmol/l) & $0.4 \pm 0.3$ & $0.8 \pm 0.5$ & 0.01 \\
\hline Insulin therapy after study $(n)$ & $11(79)$ & $6(\overline{40})$ & 0.04 \\
\hline Familial history of diabetes & $9(64)$ & $9(54)$ & NS \\
\hline Familial or personal history of autoimmunity & $11(79)$ & $8(50)$ & NS \\
\hline Dysmetabolic syndrome & $2(14)$ & $6(49)$ & NS \\
\hline \multicolumn{4}{|l|}{ HLA genotypes } \\
\hline DQB1*0201 and/or *0302 & $12(86)$ & $12(75)$ & NS \\
\hline DQB $1{ }^{*} 0201$ and ${ }^{*} 0302$ & $1(7)$ & $3(19)$ & NS \\
\hline $\mathrm{DQB} 1^{*} 0201 / x^{\mathrm{a}}$ & $10(71)$ & $9(56)$ & NS \\
\hline $\mathrm{DQB} 1^{*} 0302 / y^{\mathrm{b}}$ & $3(21)$ & $6(38)$ & NS \\
\hline $\mathrm{DQB} 1{ }^{*} 0602$ & $5(36)$ & 7 (44) & NS \\
\hline \multicolumn{4}{|l|}{ Cytokines } \\
\hline IFN- $\gamma(\mathrm{U} / \mathrm{ml})$ & $373.1 \pm 257.4$ & $331.1 \pm 196.8$ & NS \\
\hline IL-12 (pg/ml) & $289.4 \pm 253.5$ & $342.0 \pm 288.7$ & NS \\
\hline IL-4 (pg/ml) & $116.6 \pm 91.5$ & $130.6 \pm 87.1$ & NS \\
\hline $\mathrm{IL}-10(\mathrm{pg} / \mathrm{ml})$ & $1101.3 \pm 498.0$ & $1031.1 \pm 567.4$ & NS \\
\hline
\end{tabular}

Data are $n(\%)$

${ }^{a} x$ other than ${ }^{*} 0201$.

${ }^{\mathrm{b}} \mathrm{y}$ other than ${ }^{*} 0302$.

\section{Comparison of UD patients with or without $\beta$-cell autoimmune markers}

Of the 50 UD patients, 29 (58\%) had both $\beta$-cell aAbs and T-cell reactivity, while $21(42 \%)$ had neither $\beta$-cell aAbs nor T-cell reactivity. Thus these latter could be considered as non-autoimmune T2D patients (Table 3). We further compared the two subgroups, with or without $\beta$-cell autoimmune markers. Patients were similar in terms of age, sex, presence of dysmetabolic syndrome, familial history of type 1 or type 2 diabetes, age at diabetes onset, diabetes duration, basal C-peptide and C-peptide increment after glucagon stimulation, and requirement for insulin therapy after a mean follow-up of six years. However, HbAlc values were lower in UD patients with $\beta$-cell autoimmune markers $(9.1 \pm 1.8 \%$ vs $10.3 \pm 2.5 ; P=0.04)$. High-risk HLADQB1*0201 and/or HLA-DQB1*0302 genotypes were more common in patients with at least one $\beta$-cell aAb and/or at least one T-cell reactivity $(23(79 \%)$ vs 11 $(52 \%) ; P=0.04 ;$ Fig. 2). The frequency of the protective DQB $1 * 0602$ allele was similar in the two subgroups of UD patients (12 (41\%) vs 9 (43\%); NS). Similarly, familial or personal history of autoimmune disease was more frequent in UD patients with the presence of $\beta$-cell autoimmune markers (19 out of $29(65 \%)$ vs 3 out of $21(14 \%) ; P=0.0003)$. Moreover, prevalence of non- $\beta$ cell $\mathrm{aAb}$ was higher in the presence of $\beta$-cell autoimmunity (17 (59\%) vs 3 (14\%); $P=0.002)$. Finally, production of IL-4 was significantly lower in patients with $\beta$-cell autoimmune markers $(130.3 \pm 98.5$ vs
$498.1 \pm 459.1 \mathrm{pg} / \mathrm{ml} ; P=0.04)$. There was no significant difference in production of other cytokines between UD patients with or without $\beta$-cell autoimmune markers.

\section{Discussion}

We have shown the presence of PBMC reactivity against at least one of the four autoantigens tested in 16 out of $50(32 \%)$ UD patients, as opposed to 1 out of $23(5 \%)$

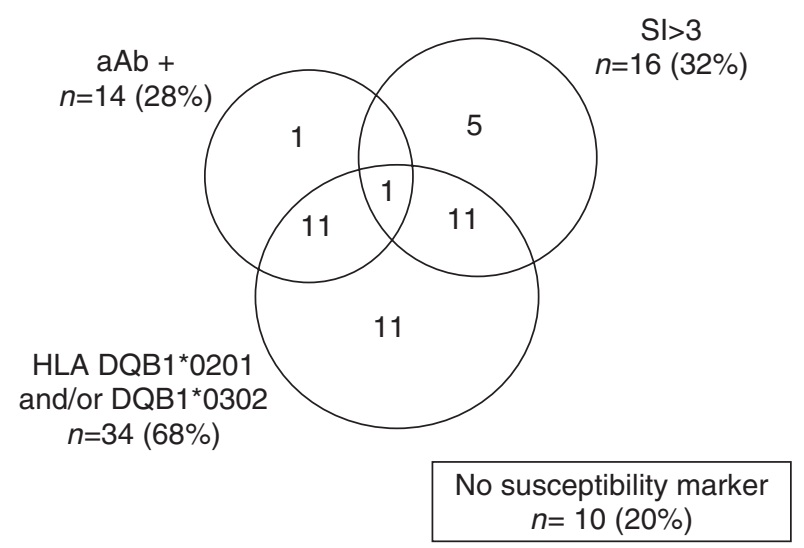

Figure 2 Frequency of autoantibodies $(\mathrm{aAb}+)$, peripheral blood mononuclear cell (PBMC) autoreactivity $(\mathrm{SI}>3)$, and susceptibility HLA genotype DQ2 and/or DQ8 associations among 50 unclassified diabetic (UD) patients. 


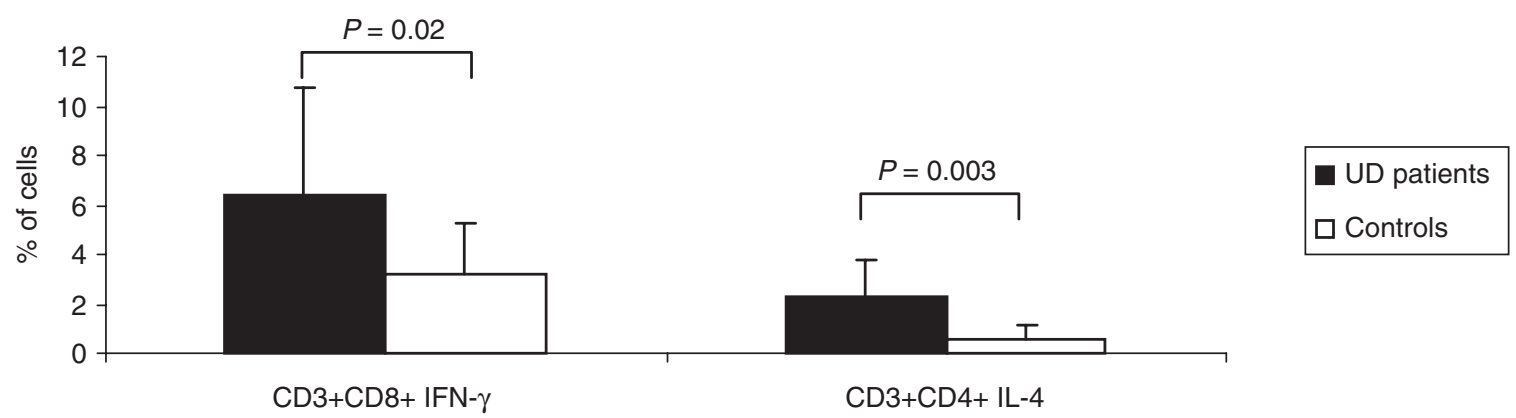

Figure 3 Secretion of cytokines after SEB stimulation (MACS cytokine secretion assay) among unclassified diabetic (UD) patients and healthy control subjects.

age- and HLA-matched normal control subjects, and 0 out of 23 classic T2D patients. For comparison, we had previously shown that 14 out of $44(32 \%)$ T1D patients had PBMC reactivity against insulin (7 out of $50(14 \%)$ in UD) and 14 out of $21(67 \%)$ had PBMC reactivity against GAD peptides (4 out of 50 (8\%) in UD). Several studies have shown peripheral T-cell autoreactivity in type 1 diabetes (11-17). Indeed, the First International Workshop on Autoreactive T-cells in Diabetes had demonstrated a need for methodological standardization
(25). In fact, several studies have failed to detect any T-cell proliferation against $\beta$-cell antigens because of a positive stimulation in control subjects $(12,26)$. In our work, the lack of proliferative responses in healthy control subjects and type 2 diabetic patients demonstrated that in vitro immunization is unlikely to occur. The quality of recombinant preparations of the autoantigens used was identified as a significant weakness $(25,27)$. We have avoided antigen preparations in E. coli, as recommended by Peakman et al.

Table 3 Characteristics of unclassified diabetic (UD) patients according to the presence or absence of at least one autoimmune marker ( $\beta$ cell autoantibody or peripheral blood mononuclear cell (PBMC) reactivity).

\begin{tabular}{|c|c|c|c|}
\hline & $\begin{array}{c}\text { Presence of } \beta \text {-cell autoimmune } \\
\text { markers }\end{array}$ & $\begin{array}{c}\text { Absence of } \beta \text {-cell autoimmune } \\
\text { markers }\end{array}$ & $\boldsymbol{P}$ \\
\hline$n$ & $29(58)$ & $21(42)$ & \\
\hline Age (years) & $53.9 \pm 11.3$ & $55.2 \pm 9.1$ & NS \\
\hline Sex & $15 \mathrm{~F} / 14 \mathrm{M}$ & $11 \mathrm{~F} / 10 \mathrm{M}$ & NS \\
\hline BMI $\left(\mathrm{kg} / \mathrm{m}^{2}\right)$ & $24.3 \pm 2.4$ & $23.5 \pm 2.0$ & NS \\
\hline Age at diabetes onset (years) & $49.6 \pm 10.7$ & $51.6 \pm 10.6$ & NS \\
\hline Duration of diabetes (years) & $4.6 \pm 4.3$ & $4.4 \pm 4.4$ & NS \\
\hline $\mathrm{HbA1c}(\%)$ & $9.1 \pm 1.8$ & $10.3 \pm 2.5$ & 0.04 \\
\hline Increment above basal C-peptide (nmol/l) & $0.6 \pm 0.5$ & $0.6 \pm 0.5$ & NS \\
\hline Insulin therapy after study $(n=48)$ & $17(\overline{6} 1)$ & $10(50)$ & NS \\
\hline Familial history of diabetes & $17(59)$ & $12(57)$ & NS \\
\hline Familial or personal history of autoimmunity & $19(65)$ & $3(14)$ & 0.0003 \\
\hline Dysmetabolic syndrome & $4(14)$ & $6(29)$ & NS \\
\hline \multicolumn{4}{|l|}{ HLA genotypes } \\
\hline DQB1*0201 and/or *0302 & $23(79)$ & $11(52)$ & 0.04 \\
\hline $\mathrm{DQB} 1{ }^{*} 0201$ and ${ }^{*} 0302$ & $3(10)$ & $2(9)$ & NS \\
\hline $\mathrm{DQB} 1{ }^{*} 0201 / x^{\mathrm{a}}$ & $18(62)$ & $9(43)$ & NS \\
\hline $\mathrm{DQB} 1{ }^{*} 0302 / y^{\mathrm{b}}$ & $8(28)$ & $4(14)$ & NS \\
\hline DQB1*0602 & $12(41)$ & $9(43)$ & NS \\
\hline Non $\beta$-cell autoantibodies & $17(59)$ & $3(14)$ & 0.002 \\
\hline ACAN & $8(28)$ & $2(10)$ & NS \\
\hline $\mathrm{TPO} A b$ & $5(17)$ & $1(5)$ & 0.04 \\
\hline Gastric $\mathrm{H}+/ \mathrm{K}+$ ATPase $\mathrm{Ab}$ & $3(10)$ & $1(5)$ & 0.03 \\
\hline FIE aAbs & 0 & 0 & NS \\
\hline SMA, LKM1, or M2 Ab & $2(7)$ & 0 & NS \\
\hline \multicolumn{4}{|l|}{ Cytokines } \\
\hline $\mathrm{IFN}-\gamma(\mathrm{U} / \mathrm{ml})$ & $359.8 \pm 223.5$ & $489.1 \pm 316.8$ & NS \\
\hline IL-12 (pg/ml) & $310.2 \pm 264.1$ & $190.8 \pm 144.5$ & NS \\
\hline $\mathrm{IL}-4(\mathrm{pg} / \mathrm{ml})$ & $130.3 \pm 98.5$ & $498.5 \pm 459.1$ & 0.04 \\
\hline IL-10 (pg/ml) & $1055.4 \pm 512.8$ & $1243.8 \pm 541.1$ & NS \\
\hline
\end{tabular}

Data are $n(\%)$. Ab, autoantibodies; ACAN, anti-nuclear cell autoantibodies; TPO, thyroperoxidase; SMA, smooth muscle antibodies; LKM1, liver-kidneymuscle1; M2, anti-mitochondrial antibodies; FIE aAbs, aAbs to intrinsic factor.

${ }^{a} x$ other than ${ }^{*} 0201$.

by other than *0302. 
(27) in the second International Workshop for Standardization of T-cell assays. Several other studies have failed because of the lack of stimulation of diabetic patients, possibly due to methodological problems such as an excessive duration between blood sampling and incubations or inhibitory effects of the antigenic preparation used (25-29). In contrast to these studies, we have developed a workable methodology in our previous studies $(16,17)$, with similar results in the present work. Moreover, we have identified similarities in antigen specificities between cellular and humoral autoimmunities. Indeed, insulin and GAD were the two most prevalent autoantigens implicated in both T-cell reactivity and $\beta$-cell aAb. As mentioned by other authors for $\beta$-cell aAb, UD patients in our study were frequently positive just for a single autoantigen in both T-cell reactivity and $\beta$-cell aAb (30).

The identification of the accurate phenotype of diabetes can be particularly difficult in clinical practice. Therefore, we have chosen to study a large population of UD patients, selected on the lack of common criteria for T1D and T2D: lack of immediate insulin needs and lack of metabolic syndrome. The 14 out of 50 (28\%) UD patients with at least one positive $\beta$-cell aAb can be considered as LADA patients, based on the classical definition of LADA. By comparison, 36 CT1D patients (82\%), no control subjects, and no classical T2D patients had at least one positive $\beta$-cell aAb. Nevertheless, $80 \%$ of our UD population showed the presence of autoimmunity, including high-risk HLA genotype, and the presence of non-specific autoimmunity like personal or familial history of non- $\beta$-cell autoimmune disease. When considering only specific $\beta$-cell autoimmunity, $29(58 \%)$ of the 50 UD patients had both $\beta$-cell aAbs and/or T-cell reactivity. Interestingly, UD patients with specific $\beta$-cell autoimmunity had high-risk HLA-DQB1*0201 and/or HLA-DQB1*0302 genotypes more often $(23(79 \%)$ vs $11(52 \%) ; P=0.04)$ and familial or personal history of autoimmune disease (19 out of $29(65 \%)$ vs 3 out of $21(14 \%) ; P=0.0003)$, in comparison with UD patients without specific $\beta$-cell autoimmunity. Thus, our data suggest that the definition of LADA, currently based on the presence of $\beta$-cell $\mathrm{aAb}$ in patients with a T2D phenotype, should also include at least theoretically patients with $\beta$-cell PBMC autoreactivity. Furthermore, UD patients with specific $\beta$-cell autoimmunity, as the controls, had lower IL-4 secretion following PHA stimulation in comparison with UD patients without $\beta$-cell autoimmune markers. Thus, UD patients without specific $\beta$-cell autoimmunity, i.e. T2D patients, seem to have a Th2 protective profile (31). Similarly, Tsiavou et al. (32) reported that CD4+ and CD8 + cells obtained from type 2 diabetic patients released significantly lower amounts of IFN- $\gamma$ as compared with those released by cells obtained from LADA patients and healthy controls.

In both UD and T1D patients, we have shown an inverse correlation between humoral and cellular $\beta$-cell autoimmunities. Interestingly, two other groups have previously described an inverse correlation between humoral and cellular $\beta$-cell autoimmunities in recentonset T1D and the first-degree relatives of T1D patients $(11,26)$. The patients studied in these previous works share with ours an adult age onset of T1D. Therefore, we wondered whether patients with $\beta$-cell aAbs and those with PBMC autoreactivity present similar or different diabetes. In keeping with our previous results in recent-onset T1D, we have observed in UD patients with the presence of peripheral PBMC autoreactivity an older age at diabetes onset and greater residual $\beta$-cell function. Thus, peripheral PBMC autoreactivity could reflect some $\beta$-cell protective effect, an observation with important therapeutic implications. It should be noted however that whereas both Th1 and Th2 cytokine productions were enhanced in the whole group of UD patients, no difference was seen between subgroups. The phenotypic characterization of autoreactive proliferating PBMCs is therefore a future challenge.

In summary, our data confirm that T-cell autoimmunity can be detected in LADA patients. Furthermore, we have shown an inverse correlation between humoral and cellular $\beta$-cell autoimmunities. In addition, the patients with $\beta$-cell PBMC autoreactivity seem to have a protective cellular response. Thus, identification of cellular $\beta$-cell autoimmunity in UD patients may be useful in determining the risk for developing precocious insulin needs and in assessing the immunologic effects of interventions aimed at altering the LADA disease process.

\section{Acknowledgements}

This research was supported by grants from the Hospices Civils de Lyon and Claude Bernard Lyon 1 University (BQR 2001). We thank G Perrin, S Veber, A Stefanutti, and A Durand for technical assistance, and C Bournaud, X Ducottet, AS Jugie, C Martin, and B Mestre for the recruitment of patients.

\section{References}

1 Report of the Expert Committee on the Diagnosis and Classification of Diabetes Mellitus. Diabetes Care 199720 1183-1197.

2 Irvine WJ, Gray RS, McCallum CJ \& Duncan LJP. Clinical and pathogenic significance of pancreatic-islet-cell antibodies in diabetics treated with oral hypoglycemic agent. Lancet 19771 1025-1027.

3 Groop L, Bottazzo GF \& Doniach D. Islet cell antibodies identify latent type 1 diabetes in patients aged 35-75 years at diagnosis. Diabetes 198635 237-241.

4 Tuomi T, Groop LC, Zimmet PZ, Rowley MJ, Knowles W \& Mackay IR. Antibodies to glutamic acid decarboxylase reveal latent autoimmune diabetes mellitus in adults with a non-insulindependent onset of disease. Diabetes 199342 359-362.

5 Tuomi T, Carlsson A, Li H, Isomaa B, Miettinen A, Nilsson A, Nilssen M, Ehrnström BO, Forsen B, Snickers B, Lahti K, 
Forsblom C, Saloranta C, Taskinen MR \& Groop LC. Clinical and genetic characteristics of type 2 diabetes with and without GAD antibodies. Diabetes $1999 \mathbf{4 8} 150-157$.

6 Fourlanos S, Dotta F, Greenbaum CJ, Palmer JP, Rolandsson O, Colman PG \& Harrison LC. Latent autoimmune diabetes in adults (LADA) should be less latent. Diabetologia $2005482206-2212$.

7 Palmer JP, Hampe CS, Chiu H, Goel A \& Brooks-Worrell BM. Is latent autoimmune diabetes in adults distinct from type 1 diabetes or just type 1 diabetes at an older age? Diabetes 200554 S62-S67.

8 Stenström G, Gottsäter A, Bakhtadze E, Berger B \& Sundkvist G. Latent autoimmune diabetes in adults. Definition, prevalence $\beta$-cell function and treatment. Diabetes $2005 \mathbf{5 4}$ S68-S72.

9 Turner R, Stratton I, Horton V, Manley S, Zimmet P, Makay IR, Shattock M, Bottazzo GF \& Holman R. UKPDS 25: autoantibodies to islet-cell cytoplasm and glutamic acid decarboxylase for prediction of insulin requirement in type 2 diabetes. UK Prospective Diabetes Study Group. Lancet $19973501288-$ 1293.

10 Keymeulen B, Vandermeulebroucke E, Ziegler AG, Mathieu C, Kaufman L, Hale G, Gorus F, Goldman M, Walter M, Candon S, Schandene L, Grenier L, De Block C, Seigneurin JM, De Pauw P, Pierard D, Weets I, Rebello P, Bird P, Berrie E, Frewin M, Waldmann H, Bach JF, Pipeleers D \& Chatenoud L. Insulin needs after CD3-antibody therapy in new-onset type 1 diabetes. New England Journal of Medicine 2005352 2598-2608.

11 Harrison LC, Honeyman MC, DeAizpurua HJ, Schmidli RS, Colman PG, Tait BD \& Cram DS. Inverse relation between humoral and cellular immunity to glutamic acid decarboxylase in subjects at risk of insulin-dependent diabetes. Lancet 1993 341 1365-1369.

12 Durinovic-Bello I, Hummel M, Standl E \& Ziegler AG. Cellular immune response to diverse islet cell antigens in IDDM. Diabetes 199645 795-800.

13 Brooks-Worrell BM, Starkebaum GA, Greenbaum CJ \& Palmer JP. Peripheral blood mononuclear cells of insulin-dependent diabetic patients respond to multiple islet cell proteins. Journal of Immunology $19961575668-5674$.

14 Atkinson MA, Kaufman DL, Campell L, Gibs KA, Shah SC, Bu DF, Erlander MG, Tobin AJ \& Maclaren NK. Response of peripheralblood mononuclear cells to glutamate decarboxylase in insulindependent diabetes. Lancet $1992339458-459$.

15 Honeyman MC, Cram DS \& Harrisson LC. Glutamic acid decarboxylase 67-reactive T cells: a marker of insulin-dependent diabetes. Journal of Experimental Medicine 1993177 535-540.

16 Mayer A, Rharbaoui F, Thivolet C, Orgiazzi J \& Madec AM. The relationship between peripheral $\mathrm{T}$ cell reactivity to insulin, clinical remissions and cytokine production in type 1 (insulin-dependent) diabetes mellitus. Journal of Clinical Endocrinology and Metabolism $1999842419-2424$.

17 Rharbaoui F, Mayer A, Granier C, Bouanani M, Thivolet C, Pau B \& Orgiazzi J. T cell response pattern to glutamic acid decarboxylase 65 (GAD65) peptides of newly diagnosed type 1 diabetic patients sharing susceptible HLA haplotypes. Clinical Experimental Immunology 1999117 30-37.

18 Brooks-Worrell BM, Juneja R, Minokadeh A, Greenbaum CJ \& Palmer JP. Cellular immune responses to human islet proteins in antibody-positive type 2 diabetic patients. Diabetes $1999 \mathbf{4 8}$ 983-988.

19 Shimada A, Imazu Y, Moringa S, Funae O, Kasuga A, Atsumi Y \& Matsuoka K. T-cell insulitis found in anti-GAD65 + diabetes with residual $\beta$-cell function. A case report. Diabetes Care 199922 615-617.

20 Expert Panel on Detection, Evaluation, and Treatment of High Blood Cholesterol in Adults. Executive Summary of the Third
Report of the National Cholesterol Education Program (NECP) Expert Panel on Detection, Evaluation, and Treatment of High Blood Cholesterol in Adults (Adult Treatment Panel III). JAMA $20012852486-2487$.

21 Petersen LS, Hejnaes KR, Moody A, Karlsen AE, Marshall MO, Hoier-Madsen M, Boel E, Michelsen BK \& Dyrberg T. Detection of GAD65 antibodies in diabetes and other autoimmune diseases using a simple radioligand assay. Diabetes $1994 \mathbf{4 3}$ 459-467.

22 Panicot L, Mas E, Thivolet C \& Lombardo D. Circulating antibodies against an exocrine pancreatic enzyme in type 1 diabetes. Diabetes $1999482316-2323$.

23 Bingley PJ, Bonifacio E \& Mueller PW. Diabetes Antibody Standardization Program: first assay proficiency evaluation. Diabetes 200352 1128-1136.

24 Deschamps I, Marcelli-Barge A, Poirier JC, Cohen-Haguenauer O, Abderrahim H, Cohen D, Lestradet H \& Hors J. Two distinct HLA-DR3 haplotypes are associated with age related heterogeneity in type 1 (insulin-dependent) diabetes. Diabetologia 1988 31 896-901.

25 Roep BO. Autoreactive T cell responses in insulin-dependent (type 1) diabetes mellitus. Report of the first international workshop for standardization of T cell assays. Journal of Autoimmunity 199913 267-282.

26 Shloot NC, Roep BO, Wegmann D, Yu L, Chase HP, Wang T \& Eisenbarth GS. Altered immune response to insulin in newly diagnosed compared to insulin-treated diabetic patients and healthy control subjects. Diabetologia 199740 564-572.

27 Peakman M, Tree TI, Endl J, van Endert P, Atkinson MA \& Roep BO. Characterization of preparations of GAD65, proinsulin, and islet tyrosine phosphatase IA-2 for use in detection of autoreactive T-cells in type 1 diabetes. Report of phase II of the Second International Immunology of Diabetes Society Workshop for Standardization of T-cell Assays in Type 1 Diabetes. Diabetes 200150 1749-1754.

28 Atkinson MA, Bowman MA, Kao KJ, Campbell P, Dush PJ, Shah SC, Simell O \& Maclaren NK. Lack of immune responsiveness to bovine serum albumin in insulin-dependent diabetes. New England Journal of Medicine 1993329 1853-1858.

29 Ellis T, Jodoin E, Ottendorfer E, Salisbury P, She JX, Schatz D \& Atkinson MA. Cellular immune responses against proinsulin: no evidence for enhanced reactivity in individuals with IDDM. Diabetes 199948 299-303.

30 Juneja R, Hirsch IB, Naik RG, Brooks-Worrel BM, Greenbaum CJ \& Palmer JP. Islet cell antibodies and glutamic acid decarboxylase antibodies, but not the clinical phenotype, help to identify type $1(1 / 2)$ diabetes in patients presenting with type 2 diabetes. Metabolism 200150 1008-10013.

31 Rabinovitch A. Immunoregulatory and cytokine imbalances in the pathogenesis of IDDM. Therapeutic intervention by immunostimulation? Diabetes 199443 613-621.

32 Tsiavou A, Hatziagelaki E, Chaidaroglou A, Koniavitou K, Degiannis D \& , Raptis SA. Correlation between intracellular interferon- $\gamma-\mathrm{IFN}-\gamma$ ) production by $\mathrm{CD} 4+$ and CD8 + lymphocytes and $I F N-\gamma$ gene polymorphism in patients with type 2 diabetes mellitus and latent autoimmune diabetes of adults (LADA). Cytokine 200531 135-141.

Received 29 January 2007

Accepted 3 May 2007 